\title{
Research on the Information Construction of the University Archives Management
}

\author{
Rili Cong ${ }^{1, a}$, Tao Feng ${ }^{2, a}$ \\ ${ }^{1}$ The Science and Technology Department of Chifeng University ,024000 ,China \\ ${ }^{2}$ The Public Security Bureau of Ningcheng County, 024000, China \\ aemail:547656850@qq.com
}

Keywords: The university, Archives management, The information construction.

\begin{abstract}
The information construction of the university archives management, is an essential part in the university management. This paper Through the analysis of its connotation, according to the problems, and then the corresponding solutions are put forward to improve the management of archives management in Colleges and universities.
\end{abstract}

\section{Introduction}

The university archives management is an essential part of university management, it plays a decisive role in the sustainable development of university management. The university archives management is mainly composed of teaching archives, enrollment activities, scientific management archives and so on. It will be a vivid image of things into abstract graphics and text and so on, convenient preservation, and constant spreads far.

The meaning of university archives management information is that it can be used to classify, utilize, develop and realize the purpose of social sharing and improve the utilization value. The university archives management information technology, the use of modern technology, the university archives resources for integration, classification, management, and the repeating use, can achieve resource sharing.

\section{The function and necessity of the construction of archives management in Colleges and Universities}

Along with the social progress and the development of science and technology, the construction of university archives management is faced with many problems and challenges. Because of the arrival of the era of digital and information technology, the technology of computer, network and other technologies affect people's daily life, and gradually become an important tool for people to live, work and study. And in order to realize the modernization of the university archives management, it is necessary to carry out the information construction of university archives management. It not only can record the history of the university, but also can record the school activities, which is full, true and objective. At the same time, it can also improve the management efficiency of the university, which has a profound influence on the university education.

\section{The problems faced by the construction of archives management in Colleges and Universities}

With the popularization of the information construction of the university archives management, the management of university archives has been developed, but there are still many problems in the process of the construction of archives management in Colleges and universities. The problems are mainly reflected in the following aspects.

The basic equipment is not perfect. The construction of archives management in Colleges and universities is based on the full range of archives management equipment, but according to the current situation of the University, most of the archives management equipment is not complete. In the construction of university archives management information, the relevant archives management 
personnel are lack of cognition, and lack of attention, which lead to the lack of information construction of university archives management, and can not be updated in time.

The university archives management information construction development progress is slow. Due to the influence of traditional archives management, the information management of the system can not be carried out. In the information management of general application, China is the use of paper management methods to save the file, so it is difficult to adapt to the process of information management, and the construction of college archives management in our country started too late, lack of infrastructure, basic equipment, which to some extent hindered the process of University archives management information construction.

Lack of targeted system management standards. Information management system standards as the basis for the high level of the university archives resources, because the lack of university archives management standards, and the lack of a complete management plan, resulting in the existence of the file management, which has a direct impact on the construction of university archives management, so that it can not achieve the resource sharing, thus impeding its development process.

Professional talent shortage. In the process of the construction of university archives management information, the professional talents are the key part of the development, and the professional archives management personnel not only need to have a solid basic knowledge, but also need to have a skilled computer operation skills. However, there are too many problems in the professional field, which is not only based on theoretical knowledge, but also the lack of relevant professional skills, can not be integrated with the basic theory and professional skills.

The Leadership awareness is not enough. At present, the majority of colleges and universities, the archives management as a part of the process of university management, the lack of attention, they think not need to spend time and energy in the archives management, it should be with the flow, according to the traditional management can not be willing to spend money on file management. Because of their lack of awareness and understanding of the construction of archives management information, the occurrence of the above phenomenon has affected the development of university archives management information construction.

\section{The effective measures for the construction of the university archives management information}

In summary, the university archives management in the process of information construction faces many problems, In order to make the university archives management information construction is effective.

Strengthening infrastructure construction. In order to make the university archives management information construction is effective, the university needs to achieve the resource sharing and the Internet, which is the original local area network. At the same time, according to the basic situation of the school, the integration of resources, planning, based on the original equipment, the purchase of new software equipment, including system software and hardware devices, in order to improve the university archives management information digital construction, we need to establish the province's university archives information network, and realize the university network information resources sharing, so that high school information network becomes part of the province's information network.

Resource setting construction

The establishment of archives information database, convenient for the archives information inquiry, this can effectively improve the work efficiency and service level to a certain extent, so as to achieve the purpose of resource sharing.

Taking the form of electronic documents for the preservation of documents to improve people's awareness of information, and often hold lectures and training, to improve the level of information technology, and promote the development of the university archives management information construction. 
Strengthening the consciousness of the archives management information, start with the work, strengthen the collection and classification of electronic documents, and ensure its accuracy, and promote the rapid development of the information construction of University Archives management.

Improving the cognition of the relevant personnel. According to the specific circumstances of the University, the university archives management information construction of the feasibility plan, so that the university's leadership to realize the necessity and importance of the file management information, so that the university archives management information construction. Therefore, the university's leadership in the archives information recognition and support is the key to the university archives management information construction, also it is the effective safeguard.

Improving the recognition of the relevant departments in the colleges and universities, This will need to some extent to eliminate the relevant personnel to the file information construction of cognitive bias, create a correct cognitive atmosphere, improve the positive initiative of all personnel, with the basic work of archives management. Archives management information work responsibilities, not only limited to the archives management personnel, it is also the responsibility of the whole university personnel,

Training professional talents. The archives management staff is an important part in the process of the construction of the archives management information. It is the bridge to maintain the file information in time, which is the operator of the information construction of archives management. Therefore, In order to promote the sustainable development of archives management in the colleges and universities, we need to train more professional talents, and the cultivation of talents should be done as follows:

A.To strengthen the training of professional knowledge. To carry out further strengthen training courses, the program Computer and other technology and modern management knowledge, and included in the training courses, improve the professional skills of the archives management.

B. regularly organized learning exchange. The universities should carry on the regular exchange of learning will, with other colleges and universities were the exchange of information, knowledge, learn from each other, the introduction of advanced concepts and methods, to improve the professional level.

C. Seting up the performance appraisal system. The training situation of the university archives management staff to join the assessment content, mobilize the enthusiasm of the file management personnel in the training process, to set a good example for the whole team, and improve the professional level of the whole team.

D. Training set management, technology and talent. The university archives management related departments need to recruit outstanding computer network personnel through different channels, after the creation of professional archives management courses, to their management training, training set management, technology in a high quality personnel.

Formulating reasonable system management standards. According to the relevant standards of the national archives, the university archives management information construction is carried out strictly. On this basis, according to the actual situation of the University, according to the actual situation to develop the system to meet the standards of the school development, the university archives management standardization and systematization.

The university archives management departments need to actively cooperate with the active participation in the system management standards related to the research and development of standards, to speed up the research process, improve the efficiency of the relevant regulations.

The construction of information resources of the university archives management. Improving the construction of information database is conducive to the realization of the information, such as file information, this can improve the work efficiency of the file management, reduce their burden of work, realize resource sharing.

Electronic document is more convenient, more intuitive and easier to read than paper documents. Therefore, it is necessary to raise the awareness of the preservation of electronic documents in Colleges and universities. By using the method of training and lectures, the level of information 
technology in college staff can be improved, and the information of archives management is realized.

Establishing a sound security system. Because the contents of the university archives contain the complete information, the information and the dynamic of the school, some information is even in the highly confidential state. It is of great significance to the development of the school. So in the process of information construction of archives management, the university archives management must be based on computer management, supplemented by artificial management, the combination of the two, for the same time management to ensure the safety of all files information, and then promote the development of university archives management.

The university archives management information and automation has replaced the traditional paper management mode, and gradually become the main management mode of university archives management. Therefore, it is necessary to improve the management of archives, to improve the work efficiency of the archives management, to realize the sustainable development of university archives management, to realize the maximum value of the management, and to improve and improve the archives management.

\section{References}

[1] Chen Cheng. On the construction of archives management in Colleges and Universities, Charm china, 2014, (13).

[2] Jiang Cuie. Research on the construction of University Archives Management Information. Business, 2013, (46)

[3] Luo Liping. On the construction of University Archives Management Information System. Urban construction theory research (electronic version) 2013, (2).

[4] $\mathrm{Hu}$ Yi. Study on informatization construction of university archives management of the. consumer electronics, 2012, (13). 